\title{
The regulation of energy metabolism and van't Hoff's rule in the homeotherm animal
}

\author{
SzILARD DONHOFFer \\ Institute of Pathophysiology, University Medical School, Pécs, Hungary
}

\begin{abstract}
KURZFASSUNG: Die Regulation des Energiestoffwechsels und die van't Hoffsche Regel beim homoiothermen Tier. Gegenüber der älteren Ansicht, daß sich der Sauerstoffverbrauch von Geweben großer und kleiner Tiere in vitro nicht unterscheide und daher der Unterschied in vivo auf einer zentralen Regulation beruhe, wird heute ziemlich allgemein angenommen, daß dies nicht der Fall sei, sondern der Sauerstoffverbrauch in vivo keiner regulativen Dämpfung unterliege. Bei homoiothermen Tieren läßt sich die Frage der Regulation des Energiestoffwechsels im Zusammenhang mit der thermoregulatorischen Wärmeproduktion sowie bei Änderungen des Energiestoff wechsels nichtthermoregulatorischer Natur untersuchen. Bei thermoregulatorischen Anderungen des Energiestoffwechsels der Ratte konnte eine integrative Regulation der Wärmeproduktion nachgewiesen werden: bei Ainderung der Beteiligung einzelner Teilprozesse (shivering und non-shivering thermogenesis) kann die Gesamtwärmebildung unverändert bleiben. Außerdem konnte gezeigt werden, daß der erhöhte Energiestoffwechsel mit Thyroxin behandelter Tiere in die thermoregulatorische Wärmeproduktion voll einbezogen wird. Versuche an Ratten mit bilateralen elektrolytischen Hypothalamus- und Epithalamusläsionen in niedrigen und hohen Umgebungstemperaturen sowie Ergebnisse über die Größe des Sauerstoffverbrauchs und der Körpertemperatur nach epithalamischen Läsionen bei niedrigen Sauerstoffdrucken erbrachten den Nachweis einer Regulation des Energiestoff wechsels nichtthermoregulatorischer Natur. Durch Ausbleiben einer Erhöhung des Energiestoffwechsels bei Hyperthermie nach Hypophysektomie, epithalamischen Läsionen etc. sowie anhand einer Analyse der Störungen der Regulation der Körpertemperatur und der Wärmeproduktion bei Hypothalamus- und Epithalamusläsionen konnte gezeigt werden, daß bestimmte Änderungen der Wärmeproduktion, die üblicherweise mit der van't Hoffschen Regel erklärt werden, durch zentralnervöse Mechanismen ausgelöst sind.
\end{abstract}

\section{INTRODUCTION}

Some time ago the question whether the metabolic rate is subject to central nervous control seemed to be rather pointless. No difference was found between the in vitro oxygen consumption of tissues of species with markedly different metabolic rates per weight in vivo, and so it was generally assumed that in the intact animal the metabolic rate of the tissues is kept under permanent control by a central regulatory mechanism (v. Bertalanffy \& Pirozynski 1951, Grafe 1925, 1934, Grafe, Reinwein \& Singer 1925, Terroine \& Roche 1925).

Since then the scene has changed; on the one hand, tissues of larger species were found to consume per weight less oxygen in vitro than tissues of smaller animals 
(Field, Belding \& Martin 1939, Kleiber 1941, Weymouth \& Field 1942, Krebs 1950, v. Bertalanffy \& Pirozynski 1951, v. Bertalanffy \& Estwick 1953, v. BerTAlanffy \& Pirozynski 1953, Fuhrman \& Fuhrman 1951, Locker 1959) and, on the other hand, interpretation of the older results changed also by taking into account

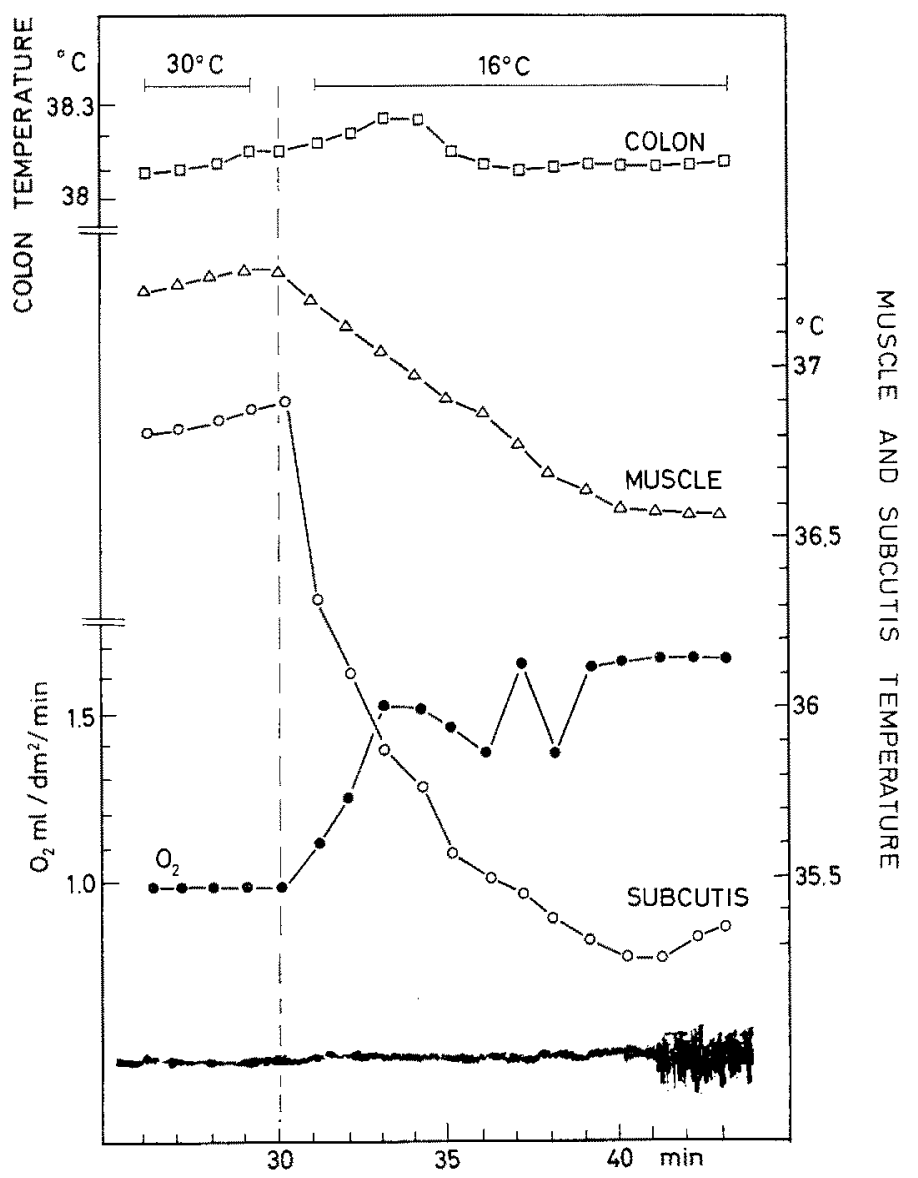

Fig. 1: Oxygen consumption, colonic temperature ( 9 to $10 \mathrm{~cm}$ from anus), lumbar muscle temperature and subcutaneous temperature in the lumbar region in a rat $0.6 \mathrm{~g}$ urethane per $\mathrm{kg}$ body weight). Temperatures were measured with thermocouples, oxygen consumption with a modified Noyons-Kipp diaferometer. (After SzegVári, VÁrNaI \& DONHOFFER 1963)

that in vitro experiments provided conditions for maximum oxygen consumption and that enzymatic reactions may proceed outside the cell at a much higher rate than inside the cell (Davies 1961).

So at present the view prevails, that the difference between the metabolic rates of large and small animals is not due to a central inhibitory mechanism, in other words, is not subject to central regulation (FuHRMAN et al. 1961).

The observation that at environmental temperatures below the neutral zone spe- 

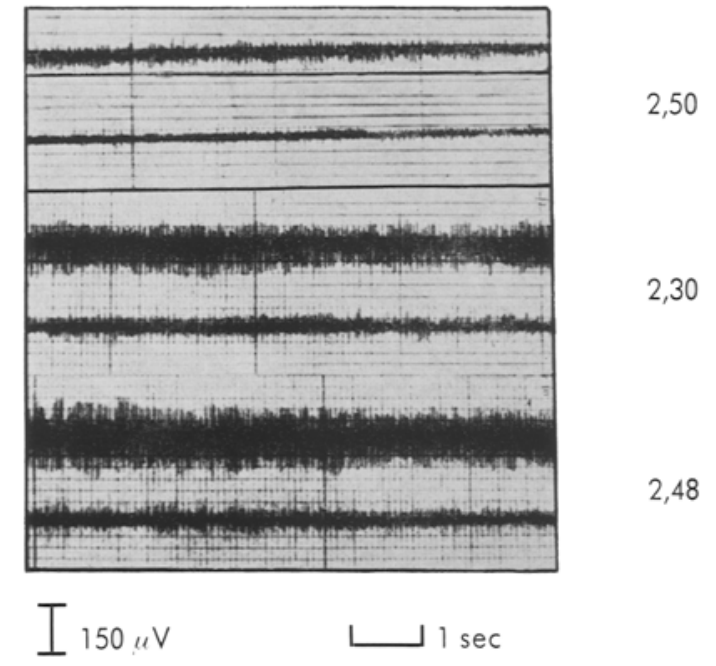

Fig. 2: Electrical activity of lumbar (upper record) and thigh muscles (lower record) in the rat $(0.5 \mathrm{~g}$ urethane per $\mathrm{kg}$ body weight). No change occurred in oxygen consumption and in electrical activity during at least 4 minutes preceding the segments of records represented; no significant change in oxygen consumption with electrical activity of widely varying intensity.

(After SZEgvári, VÁRNAI \& DONHOFFER 1963)

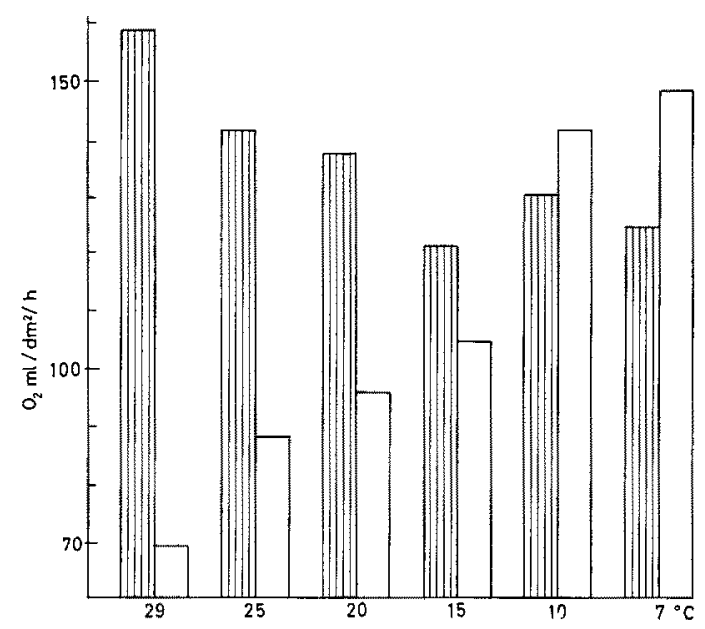

Fig. 3: Average oxygen consumption of 10 to 15 rats exposed to different environmental temperatures. Both control rats (white columns) and rats having received 150 to $200 \mu \mathrm{g}$ thyroxine per day for 6 to 8 weeks (striped columns) had been kept at room temperature. At $29^{\circ} \mathrm{C}$ - the indifferent temperature for normal rats - metabolic rates of thyroxinetreated individuals were more than 100 per cent higher. At lower temperatures metabolic rates of controls increased, whereas oxygen consumption of thyroxine-treated rats decreased until - between $10^{\circ}$ and $15^{\circ} \mathrm{C}$ - the difference between metabolic rates of controls and thyroxine-treated rats disappeared. (After ANDIK, NAGY \& TóTH 1955) 
cific dynamic action (SDA) of food disappears, i. e. is being integrated into thermoregulatory heat production, has also been questioned recently, and SDA and thermoregulatory heat production were shown to be additive (Buskirk et al. 1960). No doubt, energy metabolism responds predictably to various stimuli, but the same might be the

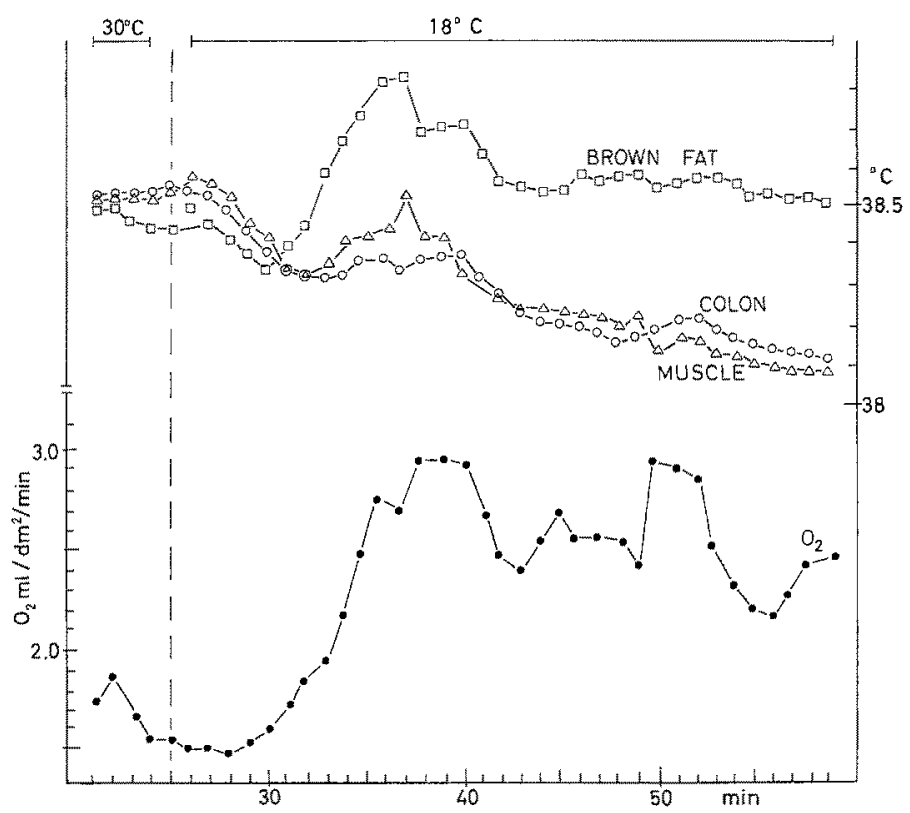

Fig. 4: Oxygen consumption of rat $(0.07 \mathrm{~g}$ hexobarbital per $\mathrm{kg}$ body weight); temperature of colon, interscapular brown fat and of muscle under the brown fat. In a thermoneutral environment $\left(30^{\circ} \mathrm{C}\right)$, colonic-, interscapular brown fat and muscle temperature are practically identical. After transfer into an ambient temperature of $18^{\circ} \mathrm{C}$, temperatures of all three sites fall together for about 4 minutes; thereafter - simultaneously with a marked increase in oxygen consumption - brown fat temperature increases sharply above the other two and maintains this level throughout cold exposure. (After Donhoffer \& SzelÉnyi 1965)

case in the absence of central regulation if only processes participating in oxygen consumption responded in a strictly determinate manner.

In the homeotherm animal regulation of thermoregulatory heat production and of non-thermoregulatory changes in energy metabolism offer themselves for investigating the problem. Demonstration of non-shivering thermogenesis in the cold-adapted (CotTle \& Carlson 1956, Depocas 1960) and the non cold-adapted rat (Donhoffer et al. 1957a) furnished the basis for analysing regulation of thermoregulatory heat production.

Methodical details of these and of the following experimental observations can be omitted since they have been published elsewhere (Donhorfer et al. 1958, Mestýn et al. 1958, 1959a, b, Szegrári, Várnai \& Donhoffer 1963, Donhofrer \& Szelényi 1965). 


\section{RESULTS AND DISCUSSION}

In the rat, processes associated with electrical activity of muscle may participate to a widely varying degree in thermoregulatory heat production without any change in total energy metabolism. Figure 1 illustrates an observation in which thermoregulatory heat production was not accompanied by electrical activity of muscle for several minutes, and thereafter the onset of electrical activity failed to increase the metabolic rate further. Figure 2 demonstrates the electrical activity of the lumbar and femoral musculature after thermal balance had been established in an environment of $21^{\circ} \mathrm{C}$. Evidently, electrical activity of very variable intensity was associated with a fairly steady level of total heat production.

Since electrical activity in muscle is associated with an increase in local oxygen consumption, unchanged total heat production indicates that heat production has been

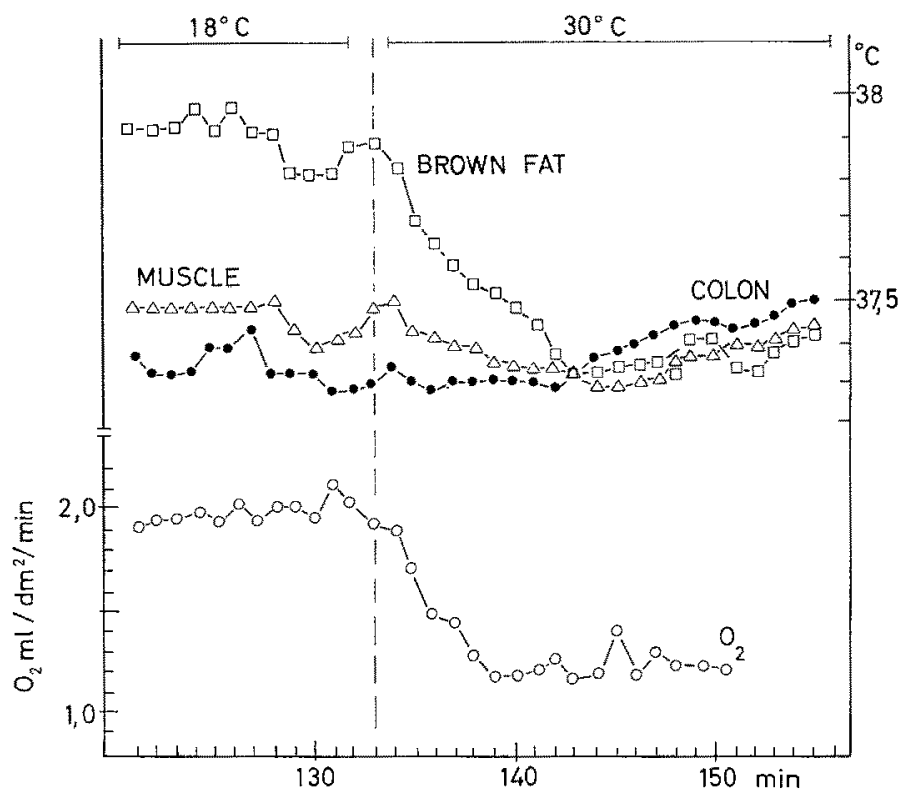

Fig. 5: Oxygen consumption of rat $(0.10 \mathrm{~g}$ hexobarbital per $\mathrm{kg}$ body weight); temperature of colon, interscapular brown fat and of muscle under the brown fat. At an ambient temperature of $18^{\circ} \mathrm{C}$, interscapular brown fat temperature was considerably higher than either colonic or muscle temperature. When the rat had been transferred from the cold to the thermoneutral environment $\left(30^{\circ} \mathrm{C}\right)$, oxygen consumption decreased immediately, and concurrently, temperature of the interscapular brown adipose tissue declined sharply, while deep colonic temperature and temperature of muscle underlying the brown fat pad showed no change. Evidently, concurrently with the decrease in oxygen consumption in the whole animal, heat production decreased sharply in the brown adipose tissue. (After Donhoffer \& SzelÉnYI 1965)

reduced by a similar amount elsewhere, demonstrating integrative regulation of thermoregulatory heat production. The thyroxine-induced increase in heat production is also completely integrated into thermoregulatory heat production. The metabolic 


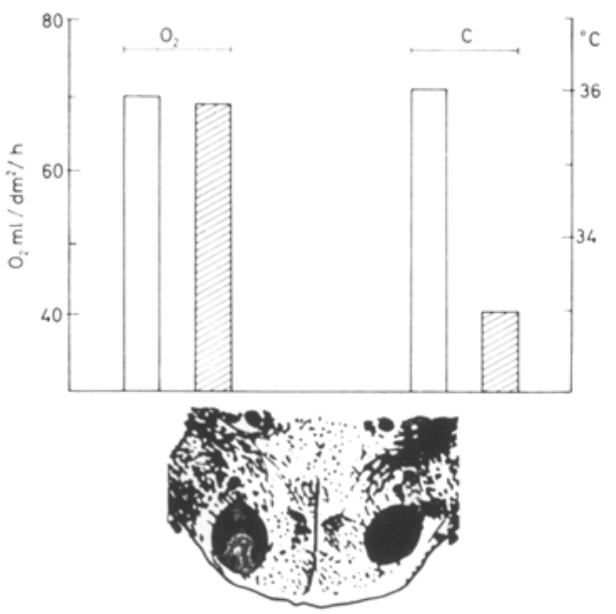

Fig. 6: Unanaesthetized rat, 48 hours after placing bilateral electrolytic lesions into the hypothalamus. Oxygen consumption (left) and colonic temperature (right) at an environmental temperature of $30^{\circ} \mathrm{C}$ (white columns) and of $20^{\circ} \mathrm{C}$ (striped columns). Oxygen consumption has been measured in three 15 minute periods; colonic temperature has been taken at the end of the third period when the rat had been exposed for 75 to 90 minutes to the experimental temperature. (After MeSTYÁN et al. 1958)

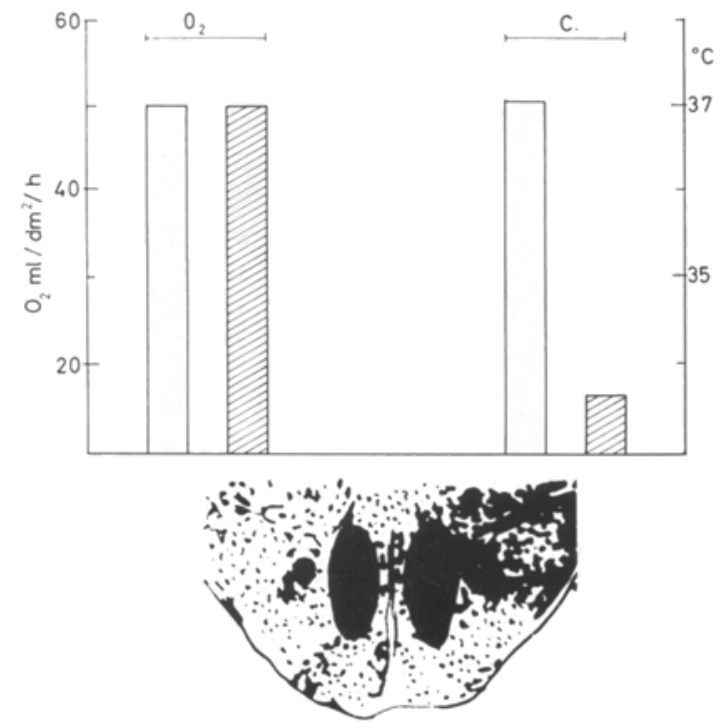

Fig. 7: Unaesthetized rat, thyroidectomized some weeks before. The experiment was performed 48 hours after the electrolytic lesions. Oxygen consumption (left) and colonic temperature (right) at $29^{\circ} \mathrm{C}$ (white columns) and at $20^{\circ} \mathrm{C}$ (striped columns). (After MEsTYÁN et al. 1958) 
rate of rats with severe hypermetabolism in warmer environments does not exceed, and may even be somewhat lower than the metabolic rate of control rats in the same cold environment (Fig. 3). The discovery of the thermogenic role of brown fat (SMITH 1962, Sмith 1964, Smith \& Hock 1963, Smith \& Roberts 1964) and its dynamic thermoregulatory response, revealed at least one of the principal mechanisms of nonshivering thermogenesis (Figs. 4,5).

The reduction in the BMR (in a thermoneutral environment) observed not unfrequently after bilateral hypothalamic lesions (Grafe \& Grünthal 1929, Mestyán et al. $1959 \mathrm{~b}$ ) might also be interpreted to indicate regulation of energy metabolism

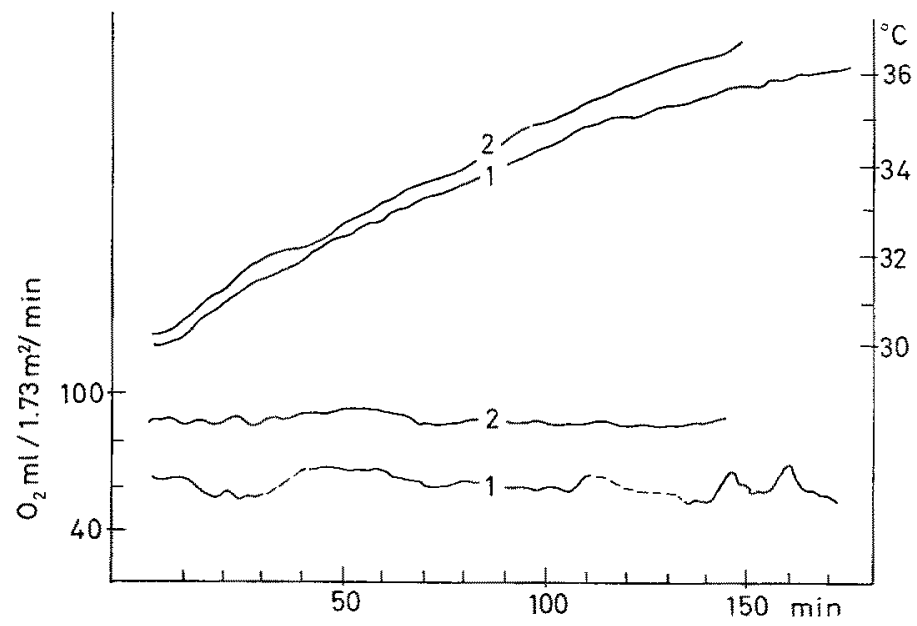

Fig. 8: Oxygen consumption (lower lines) and rectal temperature (upper lines) of two human premature neonates without signs of thermoregulation. In an adequately warm environment rectal temperature increased by about $6^{\circ} \mathrm{C}$ without any change in the metabolic rate. (After MESTYÁn et al. 1962)

independently of thermoregulatory heat production. Such an interpretation would not be, however, quite convincing. The same applies even more to the frequent increases in the BMR after hypothalamic and epithalamic lesions, which may, or may not, be associated with febrile body temperatures (MESTYÁN et al. 1958, MESTXÁN et al. 1959a, b, Donhoffer et al. 1959b).

Regulation of energy metabolism of non-thermoregulatory origin might be investigated (a) after abolition of thermoregulation and (b) in the course of responses independent of thermoregulatory mechanisms. In the absence of thermoregulation, resting energy metabolism of the animal is generally held to follow van't Hoff's rule, i. e. to vary with body temperature with a $Q_{10}$ between 2 and 3. Deviations from van't Hoff's rule, considered to originate in the peripheral tissues, have been observed by O'ConNor (1949) in both poikilotherm and homeotherm animals. Nevertheless, any deviations from van't Hoff's rule of central origin in non-thermoregulatory responses, or after abolition of thermoregulation might furnish evidence for central regulation of energy metabolism independently of thermoregulatory heat production. 
Three types of observations seemed to offer promising hints: (a) the relationship of body temperature and oxygen consumption at environmental temperatures below the thermoneutral zone after having abolished thermoregulatory heat production;

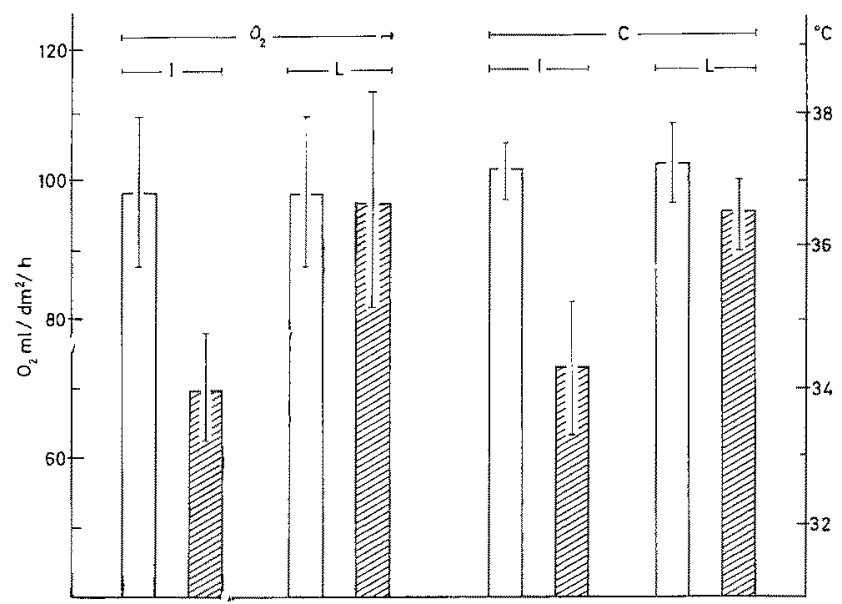

Fig. 9: Means and standard errors of oxygen consumption (left) and colonic temperature (right) of intact rats (I) and rats with bilateral epithalamic lesions (L) which had abolished the response to hypoxia without imparing the thermoregulatory increase in heat production in response to cold. Oxygen consumption and body temperature at $22^{\circ} \mathrm{C}$ and atmospheric pressure (white columns) and a pressure of $420 \mathrm{Hg} \mathrm{mm}$ (striped columns). At atmospheric pressure both oxygen consumption and body temperature are identical in the intact and the lesioned group, demonstrating that thermoregulation has not been impaired by the lesions. (After DoNhofFer et al. 1957b)

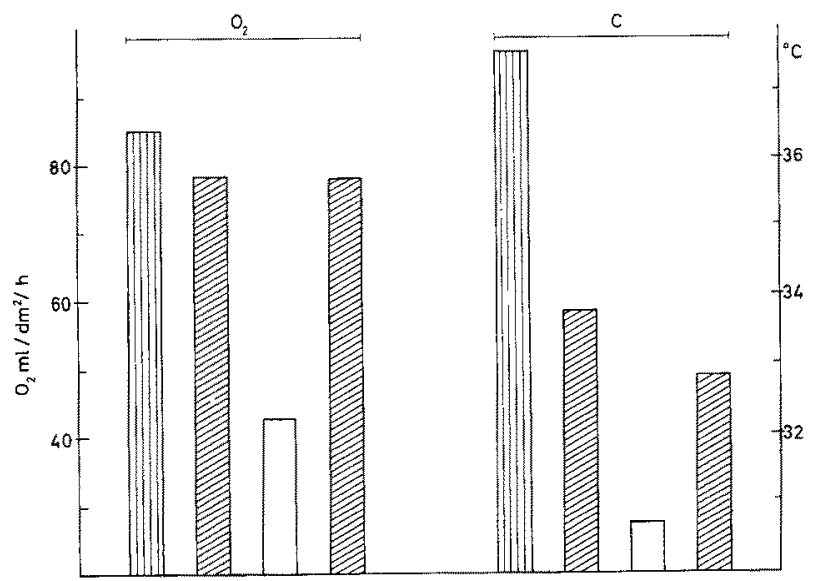

Fig. 10: Unaesthetized rat with bilateral electrolytic lesions in the epithalamus. Oxygen consumption (left) and colonic temperature (right) at $30^{\circ} \mathrm{C}$ and atmospheric pressure (longitudinal stripes), at $23^{\circ} \mathrm{C}$ and atmospheric pressure (oblique stripes), and at $23^{\circ} \mathrm{C}$ at a pressure of $420 \mathrm{~mm} \mathrm{Hg}$ (white columns). That the response to hypoxia was a specific one is demonstrated convincingly by the fact that after restoring atmospheric pressure without any change in the ambient temperature, oxygen consumption and body temperature approached the level observed prior to exposure to hypoxia. (After Donhoffer et al. 1957) 
(b) analysis of the response of body temperature and energy metabolism to hypoxia; and (c) analysis of the increase in heat production in response to hyperthermia.

Rats in which thermoregulatory heat production had been abolished by bilateral electrolytic lesions in the hypothalamus, showed clearly that although oxygen con-

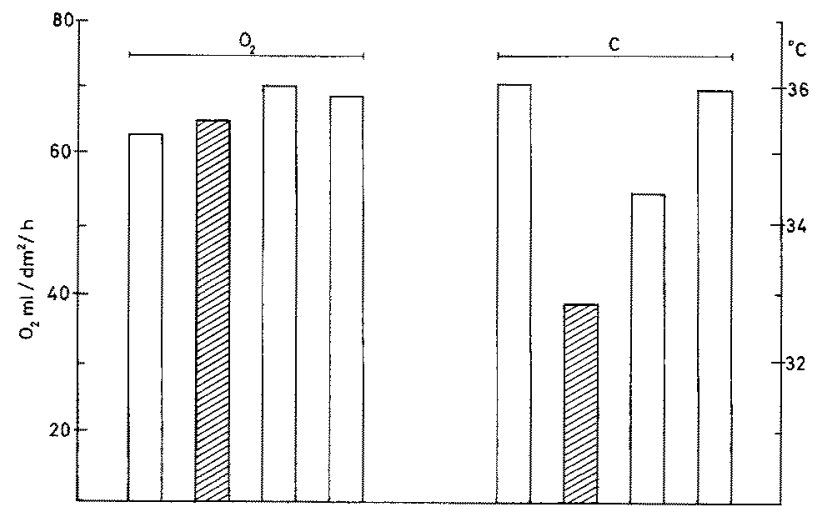

Fig. 11: Unanaesthetized rat with bilateral epithalamic lesions. Oxygen consumption (left) and rectal temperature (right) at an ambient temperature of $22^{\circ} \mathrm{C}$ and atmospheric pressure (white columns) and at the same temperature at $420 \mathrm{~mm} \mathrm{Hg}$ (striped columns). The lesions had abolished the thermoregulatory increase in heat production; the metabolic rate was the same in an environment of $22^{\circ} \mathrm{C}$ as in a thermoneutral one, but no hypothermia developed. Oxygen consumption failed to decline in response to exposure to an ambient pressure of $420 \mathrm{~mm} \mathrm{Hg}$; body temperature, however, declined by $3^{\circ} \mathrm{C}$ during the exposure to the reduced pressure. The specificity of this response is demonstrated by the fact that after restoring atmospheric pressure, body temperature reached again the pre-hypoxic level although there was no change in ambient temperature. (After DoNHOFFer et al. 1957b)

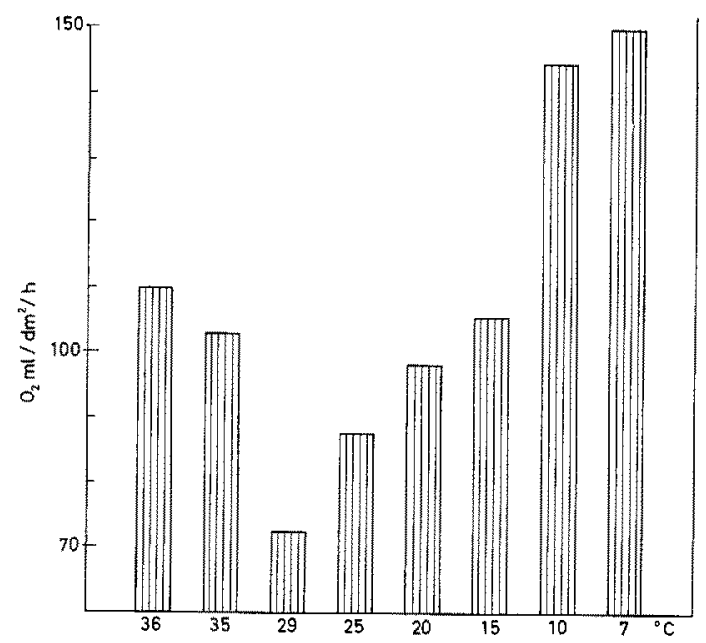

Fig. 12: Oxygen consumption of intact rats exposed to various ambient temperatures in an environment practically saturated with water vapour. All differences, except for that between $10^{\circ}$ and $7^{\circ} \mathrm{C}$, are statistically significant. The increase in heat production at environmental temperatures leading to hyperthermia has never been missed in the intact animal 
sumption may fail to increase subsequent to exposure to a cool environment, it may be maintained at the same level in spite of a fall in body temperature of several centigrades (Figs. 6, 7). Somewhat similar observations were made by Mestyán et al. (1962) on premature neonates showing no signs of thermoregulation. Body temperature varied by more than $6^{\circ} \mathrm{C}$, yet oxygen consumption remained unchanged (Fig. 8).

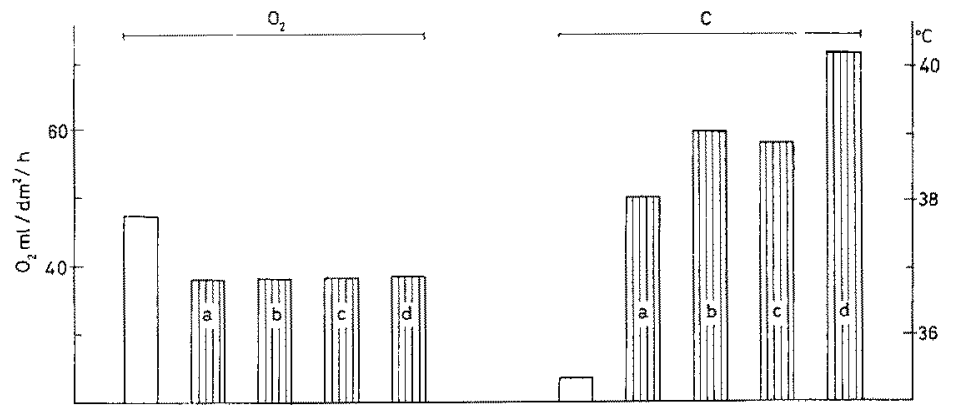

Fig. 13: Oxygen consumption (left) and colonic temperature (right) of an unanaesthetized rat, hypophysectomized five months earlier, at an ambient temperature of $29^{\circ} \mathrm{C}$ (white columns) and during exposure to: (a) $35.0^{\circ} \mathrm{C}$, (b) $37.5^{\circ} \mathrm{C}$, (c) $38.5^{\circ} \mathrm{C}$, (d) $39.5^{\circ} \mathrm{C}$, respectively (longitudinal stripes). Despite hyperthermia no increase in heat production. (After BALOGH et al. 1952)

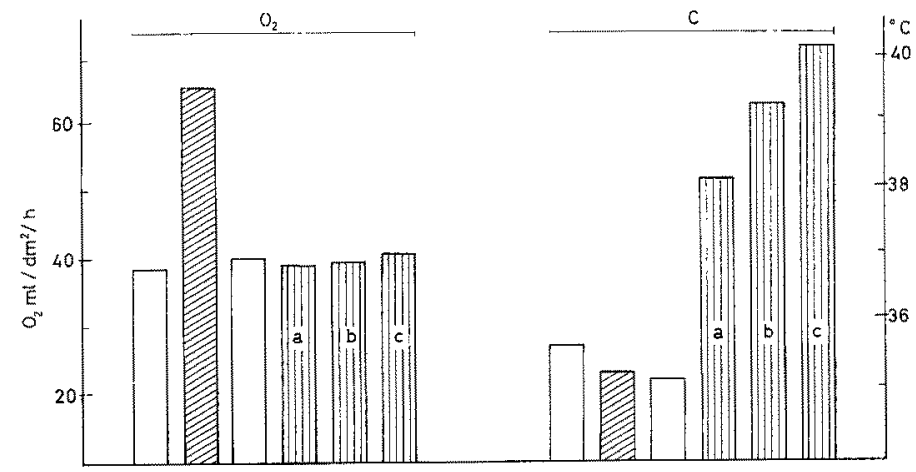

Fig. 14: Unanaesthetized rat having received 0.1 per cent of methylthiouracil in the food for five weeks. Oxygen consumption (left) and colonic temperature (right) in an environment of $29.4^{\circ} \mathrm{C}$ (white columns), exposed to an ambient temperature of $22.9^{\circ} \mathrm{C}$ (oblique stripes) and in the course of exposure to: (a) $35.2^{\circ} \mathrm{C}$, (b) $37.3^{\circ} \mathrm{C}$ and (c) $38.6^{\circ} \mathrm{C}$ (longitudinal stripes). Methylthiouracil had abolished the metabolic response to hyperthermia, whereas the metabolic response to cold was not impaired. (After BALOGH et al. 1952)

These observations undoubtedly indicate that even in the absence of thermoregulatory responses energy metabolism is not governed by van't Hoff's rule. However, since heat production remained unchanged, they do not demonstrate unequivocally that the metabolic rate is being integratively regulated.

At ambient temperatures below the thermoneutral zone the rat responds even to a moderate reduction of oxygen tension invariably with a fall in oxygen con- 
sumption and body temperature (LINTZEL 1931). It was possible to show that reduction of heat production and of body temperature are both mediated by central nervous mechanisms, since the response could be abolished completely by epithalamic lesions

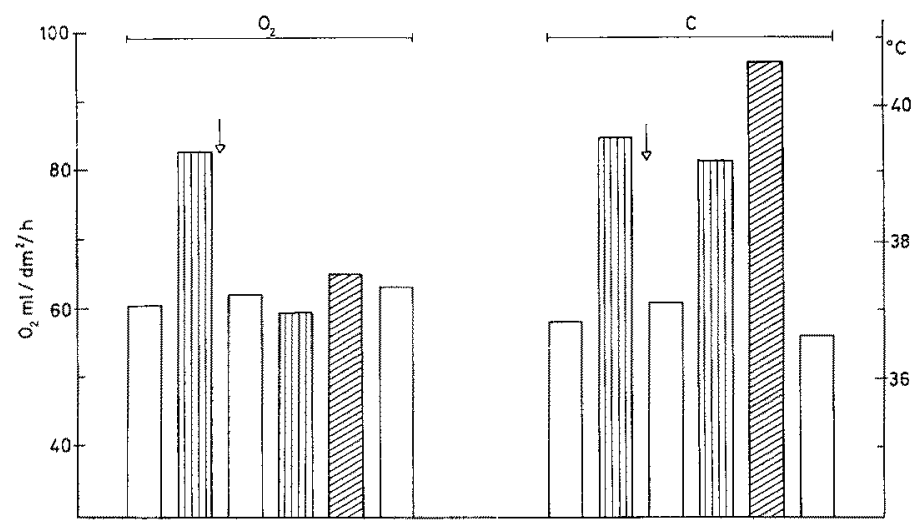

Fig. 15: Oxygen consumption of rat (left) and colonic temperature (right) in a thermoneutral environment of $29^{\circ} \mathrm{C}$ (white columns) and at ambient temperatures of $35^{\circ} \mathrm{C}$ (longitudinal stripes) and $36^{\circ} \mathrm{C}$ (oblique stripes) before and after subcutaneous administration of urethane (arrow). Urethane abolished the response of oxygen consumption to hyperthermia completely. (After DONHOFFER et al. 1953a)

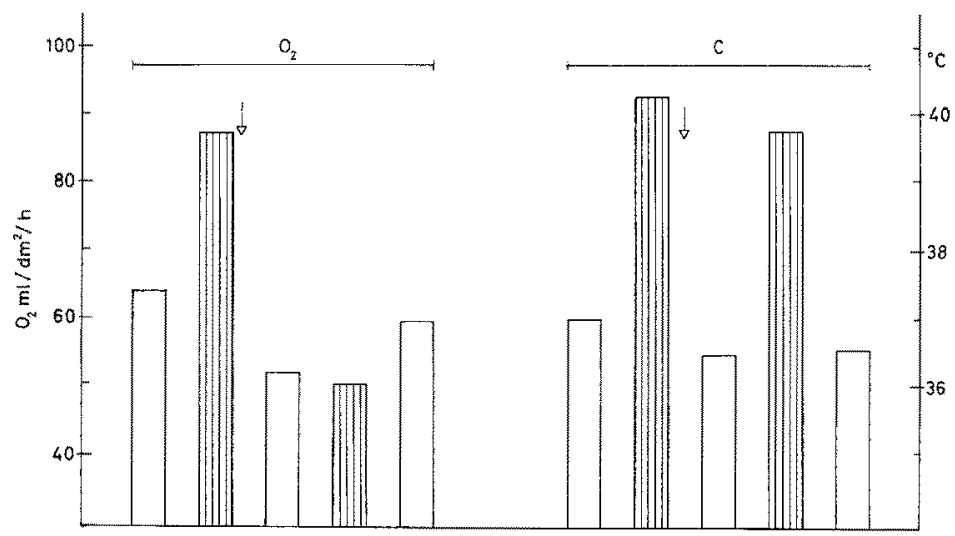

Fig. 16: Oxygen consumption of rat (left) and colonic temperature (right) at an ambient temperature of $29^{\circ} \mathrm{C}$ (white columns) and at one of $36^{\circ} \mathrm{C}$ (longitudinal stripes) before and after subcutaneous administration of chloralhydrate (arrow). Chloralhydrate abolished the hyperthermic increase in heat production completely. (After DonHofrer et al. 1953a)

without necessarily impairing thermoregulatory responses at normal atmospheric oxygen tension (Fig. 9). The high degree of independence of thermoregulatory and hypoxic tesponses has been pointed out also by observations in which thermoregulation had been severely impaired in the animal and yet the response to hypoxia has been maintained (DoNHoffer et al. 1957b). 
Figure 10 illustrates an experiment conducted on a rat in which the lesions abolished the thermoregulatory response. At an ambient temperature of $23^{\circ} \mathrm{C}$ heat production failed to increase and body temperature decreased by $4^{\circ} \mathrm{C}$. When oxygen tension was reduced to $420 \mathrm{~mm} \mathrm{Hg}$, oxygen consumption decreased by almost 50 per cent and body temperature fell an additional $3^{\circ} \mathrm{C}$. The regulatory nature of the response is revealed by the fact that, without any change in ambient temperature, heat production rose to the initial level after atmospheric oxygen tension had been restored. In addition, the responses of body temperature and energy metabolism are not strictly

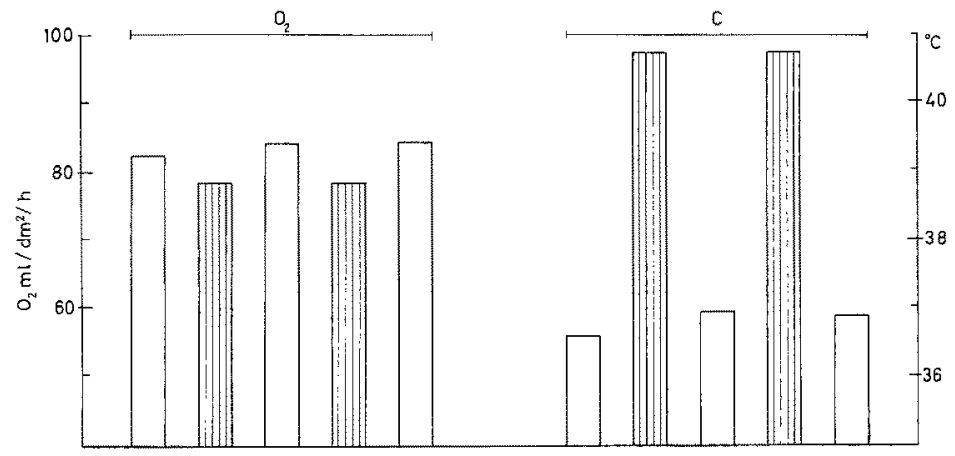

Fig. 17: Unanaesthetized rat with bilateral electrolytic lesions in the epithalamus involving the ganglia habenulae. Oxygen consumption (left) and colonic temperature (right) in a thermoneutral environment (white columns) and at an ambient temperature of $36^{\circ} \mathrm{C}$ (longitudinal stripes). No increase in heat production despite very marked hyperthermia. (After DONHOFFER et al. 1953a)

linked. Figure 11 demonstrates the responses of a rat in which reactions of energy metabolism to hypoxia had been completely abolished by the epithalamic lesion, whereas body temperature dropped more than $3^{\circ} \mathrm{C}$.

Abolition of the hypoxic response of energy metabolism without impairment of the thermoregulatory response represents strong evidence for the existence of a central regulation of energy metabolism independent of the regulation of heat production. Evidence is strengthened further by observations in which the response to hypoxia persisted although thermoregulatory heat production had been abolished by the epithalamic lesions.

The fact that the metabolic response to hypoxia and the thermoregulatory increase in heat production may be both abolished and body temperature may nevertheless fall by several centigrades during hypoxia, demonstrates that the hypoxic fall in heat production is not dependent on a mechanism governed by van't Hoff's rule.

The mechanism of the increase in metabolic rate in response to hyperthermia has received little attention. According to the the generally held view, it finds a satisfactory explanation in the operation of van't Hoff's rule. The increase in oxygen consumption in hyperthermia represents a 100 per cent response; no exceptions were found in intact animals (Fig. 12). In addition, the increase in the metabolic rate is compatible with a $\mathrm{Q}_{10}$ between 2 and 3. The generality of the phenomenon and the 


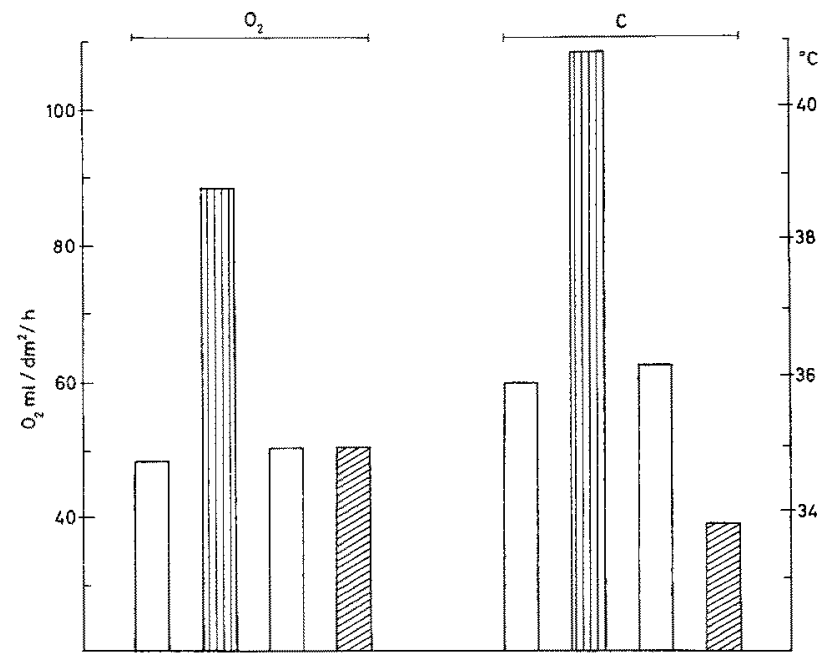

Fig. 18: Unanaesthetized rat with bilateral lesions in the tuberal region of the hypothalamus. Oxygen consumption (left) and colonic temperature (right) in a thermoneutral environment (white columns) at an ambient temperature of $35^{\circ} \mathrm{C}$ (longitudinal stripes) and at $20^{\circ} \mathrm{C}$ (oblique stripes). The lesions had abolished the thermoregulatory increase in heat production in response to cold, whereas the metabolic response to hyperthermia had been preserved. (After Mestyán et al. 1959a)

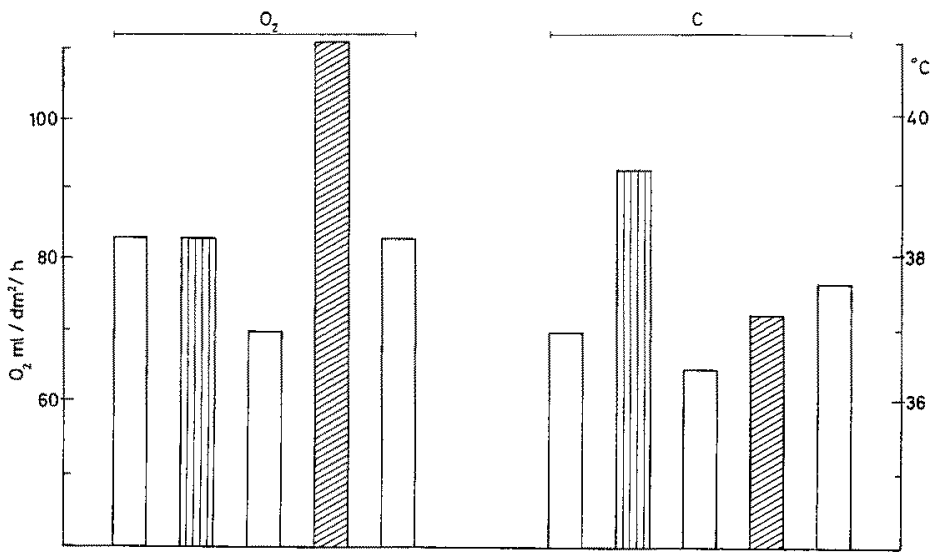

Fig. 19: Unanaesthetized rat with bilateral epithalamic lesions involving both ganglia habenulae. Oxygen consumption (left) and colonic temperature (right) at an ambient temperature of $29^{\circ} \mathrm{C}$ (white columns), $36^{\circ} \mathrm{C}$ (longitudinal stripes) and $23^{\circ} \mathrm{C}$ (oblique stripes). The increase in heat production in response to hyperthermia had been abolished by the lesions, whereas the metabolic response to cold was not impaired. (After Donhoffer et al. 1953a)

compatibility of the $Q_{10}$ with van't Hoff's rule represent all the evidence for the ruling assumption. With some benevolence this evidence might perhaps be called circumstantial, however, it has been almost unanimously accepted.

It can be demonstrated convincingly in several ways, that this generally held 
view is, nevertheless, completely erroneous. If the hyperthermic increase in energy metabolism would be simply the consequence of the operation of van't Hoff's rule, there evidently should be no exceptions, yet the metabolic response to hyperthermia has been abolished in a variety of ways.

The rat fails to respond to hyperthermia with an increase in metabolic rate after thyroidectomy and after hypophysectomy (Fig. 13); the response could be abolished by methylthiouracil treatment (Fig. 14) and was found to disappear during the effect of urethane and chloralhydrate but not under the effect of barbiturates (Figs. 15, 16).

These results already indicate that the metabolic response to hyperthermia instead of being a consequence of the operation of van't Hoff's rule - is being mediated by a central nervous mechanism. Convincing proof for the central nervous origin was furnished by observations demonstrating that the response can be abolished by bilateral epithalamic lesions, and with lesser frequency also by hypothalamic lesions (Fig. 17).

Similar experiments demonstrated, in addition, that the increase in metabolic rate in response to cold and in response to hyperthermia are mediated by separate central mechanisms. Lesions may abolish the metabolic response to cold without affecting the hyperthermic increase in heat production (Fig. 18); the reverse also holds, lesions may abolish the response to hyperthermia without interfering with the increase in heat production in response to cold (Fig. 19).

These results show unequivocally that (a) increased heat production during hyperthermia is not due to the operation of van't Hoff's rule, and that (b) increased heat production in response to cold and to hyperthermia is not mediated by the same central mechanism.

In themselves, these experiments furnish, however, no compelling evidence that the response to hyperthermia is independent of thermoregulatory processes. It has actually been proposed that the increase in oxygen consumption during hyperthermia might be, at least in part, due to the energy requirement of the increased activity of mechanisms of heat loss and thus serve thermoregulation indirectly.

Table 1

Oxygen consumption and colonic temperature of thyroidectomized, hypophysectomized and methylthiouracil treated rats in response to hyperthermia; means and standard errors. (After Donhoffer et al. 1953b)

\begin{tabular}{|lcccc|}
\hline Criteria & \multicolumn{2}{c|}{$\begin{array}{c}\text { Indifferent temperature: } 29^{\circ} \mathrm{C} \\
\text { Before thyroxin }\end{array}$} & $\begin{array}{c}\text { High temperature: } 35^{\circ} \text { to } 37^{\circ} \mathrm{C} \\
\text { After thyroxin }\end{array}$ & $\begin{array}{c}\text { Before thyroxin } \\
\text { After thyroxin }\end{array}$ \\
\hline $\begin{array}{l}\text { O consumption } \\
\text { ml/dm } / \mathrm{h}\end{array}$ & $45 \pm 1$ & $45 \pm 1$ & $44 \pm 1$ & $58 \pm 1$ \\
Body temperature & $35.9 \pm 0.11$ & $35.9 \pm 0.11$ & $38.8 \pm 0.08$ & $38.8 \pm 0.08$ \\
\hline
\end{tabular}

In such a case it might be expected that the absence of the hyperthermic increase would indicate a lesser activity of the mechanisms of heat loss, and therefore body temperature should reach a higher level in the same environment as in the presence of the metabolic response. 
If - in contrast - increase in metabolic rate during hyperthermia was not associated with the increased activity of mechanisms of heat loss, body temperature might be expected to rise to a higher level in the presence of an augmented heat production, than in its absence.

The answer produced through a statistical analysis of our results was rather unexpected: none of the two alternatives actually occurred. Body temperature was found to be the same; whether heat production increased during hyperthermia or not.

Table 1 shows that body temperature of thyroidectomized rats rose to exactly the same level in the absence of an increase in oxygen consumption and after this increase had been restored by small permissive doses of thyroxine not affecting body temperature and metabolic rate in the thermoneutral environment.

Table 2

Oxygen consumption and colonic temperature of rats with bilateral hypothalamic lesions at ambient temperatures of $29^{\circ}$ and $35^{\circ} \mathrm{C}$ in the presence and absence of metabolic response to hyperthermia; means and standard errors. (After DonHoffer et al. 1959a)

\begin{tabular}{|lcccc|}
\hline Criteria & \multicolumn{2}{c}{$\mathrm{O}_{2}$ consumption $\mathrm{ml} / \mathrm{dm}^{2} / \mathrm{h}$} & \multicolumn{2}{c|}{ Colonic temperature } \\
& $29^{\circ} \mathrm{C}$ & $35^{\circ} \mathrm{C}$ & $29^{\circ} \mathrm{C}$ & $35^{\circ} \mathrm{C}$ \\
\hline $\begin{array}{l}\text { Hyperthermic increase } \\
\text { maintained } \mathrm{n}=36\end{array}$ & $71 \pm 2.3$ & $94 \pm 2.8$ & $37.3 \pm 0.11$ & $39.9 \pm 0.13$ \\
$\begin{array}{l}\text { Hyperthermic increase } \\
\text { absent } \mathrm{n}=30\end{array}$ & $77 \pm 3.3$ & $77 \pm 3.2$ & $37.6 \pm 0.17$ & $39.9 \pm 0.14$ \\
\hline
\end{tabular}

Table 2 demonstrates the same situation in animals with hypothalamic lesions. Body temperature rose in the warm environment to the same level whether the increase in oxygen consumption had been abolished by the lesion or not. These results suggest that the metabolic response to hyperthermia is not linked to thermoregulatory mechanisms and, of course, show also that hyperthermia is not simply the consequence of passive heat storage but represents a body temperature regulated at a higher level.

\section{SUMMARY}

1. Shivering and non-shivering thermoregulatory heat production in response to cold as well as exposure of thyroxine-treated rats to low temperatures demonstrate the existence of an integrative regulation of energy metabolism.

2. Responses of rats with hypothalamic and epithalamic lesions to cold and heat, and with epithalamic lesions to hypoxia furnished evidence for central regulation of energy metabolism independently of thermoregulation.

3. By abolishing the increase in heat production in response to hyperthermia and by analysis of observations on animals with hypothalamic and epithalamic lesions, it could be demonstrated convincingly that responses of energy metabolism, apparently comparible with van't Hoff's rule, are actually mediated by central nervous mechanisms. 


\section{LITERATURE CITED}

Andik, I., NAGY, L. \& Tóth, I., 1955. Uber die Wirkung der Umgebungstemperatur auf den Stoffwechsel normaler und mit Thyroxin behandelter Ratten. Acta physiol. bung. 8, $399-404$.

Balogh, L., Donhoffer, Sz., Mestyán, Gy., Pap, T. \& Tóth, I., 1952. The response of oxygen consumption of thyroidectomized, hypophysectomized and methylthiouracil treated rats to high environmental temperatures and the action of thyroxine thereon. Acta physiol. bung. 3, 395-403.

BERTALANFFy, L. \& Estwick, R. R., 1953. Tissue respiration of musculature and body size. Am. J. Pbysiol. 173, 58-60.

- \& Pirozynski, W. J., 1951. Tissue respiration and body size. Science, N. Y. 113, 599-600.

- - 1953. Tissue respiration, growth, and basal metabolism. Biol. Bull. mar. biol. Lab., Woods Hole 105, 240-256.

Buskirk, E. R., Thompson, R. H., Moore, R. \& Whedon, G. D., 1960. Human energy expenditure studies in the National Institute of Arthritis and Metabolic Diseases, Metabolic Chamber. Am. J. clin. Nutr. 8, 602-613.

CotTLE, W. H. \& Carlson, L. D., 1956. Regulation of heat production in cold-adapted rats. Proc. Soc.exp. Biol. Med. 92, 845-849.

Davres, M., 1961. On body size and tissue respiration. J. cell. comp. Physiol. 57, 135-147.

Depocas, F., 1960. Calorigenesis from various organ systems in the whole animal. Fedn Proc. Fedn Am. Socs exp. Biol. 19 (Suppl. 5), 19-25.

Donhoffer, Sz., Mestyán, Gy., Pap-Obrincsák, E., Pap, T. \& Tóth, I., 1953a. The mechanism of the rise in oxygen consumption in hyperthermia. Acta physiol. bung. 4, 63-69.

- Mestyán, Gr., Orrincsák, E., Pap, T. \& Tóth, I., 1953b. The thermoregulatory significance of the increase in oxygen consumption elicited by high environmental temperature. Acta physiol. hung. 4, 291-299.

- Szegvári, Gy., Varga-Nagy, I. \& Járat, I., 1957a. Über die Lokalisation der erhöhten Wärmeproduktion bei der chemischen Wärmeregulation. Pflügers Arch. ges. Physiol. 265, 104-111.

- Mestyán, Gy., Nagy, L. \& Szegvári, Gy., 1957b. Uber den Mechanismus der hyperthermischen Steigerung und der hypoxischen Senkung des Energiewechsels. Acta neuroveg. 16, 390-399.

- Szegvári, Gy., Varga-Nagy, I., Járax, I. \& Haug-László, Á, 1958. Öber die Dynamik der chemischen Wärmeregulation der Ratte. Acta physiol. bung. 13, 37-56.

- Mestyán, Gy., Szegvári, Gy. \& Járar, I., 1959a. Die thermoregulatorische Bedeutung der hyperthermischen Umsatzsteigerung. Versuche nach Läsionen des Hypothalamus und des Epithalamus. Acta physiol. hung. 15, 145-150.

- Mestyán, Gy., Mess, B., Szegvári, Gy. \& Járai, I, 1959b. Über die Wirkung von Epithalamusläsionen auf Umsatz und Körpertemperatur der Ratte und deren Vergleich mit dem Verhalten nach Hypothalamusläsionen. Acta physiol. hung. 15, 161-177.

- \& SZELÉnYI, Z., 1965. The role of brown adipose tissue in thermoregulatory heat production in the non cold-adapted adult rat, guinea pig and ground squirrel and in the young rabbit. Acta physiol. bung. 28, 349-361.

Field, J., Belding, H. S. \& Martin, A. W., 1939. An analysis of the relation between basal metabolism and summated tissue respiration in the rat. 1 . The post-pubertal albino rat. J. cell. comp. Pbysiol. 14, 143-157.

Furrman, F. A. \& Futrman, G. J., 1957. Metabolism of rat skin in vitro with special reference to effect of body size on tissue metabolism. J. appl. Physiol. 10, 219-223.

- Furrmann, G. J., Farr, D. A. \& Fail, J. H., 1961. Relationship between tissue respiration and total metabolic rate in hypo- and normothermic rats. Am. J. Physiol. 201, 231-234.

Grafe, E., 1925. Die nervöse Regulation des Stoffwechsels. In: Handbuch der Biochemie des Menschen und der Tiere. Hrsg. von C. Oppenheimer. 2. Aufl. Fischer, Jena, Bd 9 (T. 10)

- 1934. Wärmehaushalt und endokrines System. Klin. Wschr. 13, 1705-1709. 
- \& Grünthal, E., 1929. Über isolierte Beeinflussung des Gesamtstoffwechsels vom Zwischenhirn aus. Klin. Wschr. 8, 1013-1016.

- Reinwein, H. \& Singer, V., 1925. Studien über Gewebsatmung. 2. Mitt.: Die Atmung der überlebenden Warmblüterorgane. Biochem. Z. 165, 102-117.

Klerber, M., 1941. Body size and metabolism of liver slices in vitro. Proc. Soc. exp. Biol. Med. 48, 419-423.

Krebs, H. A., 1950. Body size and tissue respiration. Biochim. biopbys. Acta 4, $249-269$.

LinTZEL, W., 1931. Über die Wirkung der Luftverdünnung auf Tiere. 5. Mitt.: Gaswechsel weißer Ratten. Pflügers Arch. ges. Physiol. 227, 693-708.

LOCKER, A., 1959. Temperatur als wesentlicher Parameter für die Größenabhängigkeit von Lebensvorgängen. Experientia 15, 100-101.

Mestyán, Gy., Mess, B., Szegvári, Gy. \& Donhoffer, Sz, 1958. Über das Verhalten des Umsatzes und der Körpertemperatur der Ratte in einer kühlen Umgebung nach bilateralen Hypothalamusläsionen. Acta pbysiol. bung. 14, 273-286.

- Mess, B., Szegyári, Gy. \& Donhoffer, Sz., 1959a. Uber das Verhalten des Umsatzes der Ratte nach Hypothalamusläsionen in der Wärme und dessen Beziehungen zur Thermoregulation in kühler Umgebung. Acta physiol. hung. 15, 89-98.

- Mess, B., Szegrári, Gy. \& Donhoffer, Sz., 1959b. Über das Verhalten des Grundumsatzes und der Körpertemperatur der Ratte nach bilateralen, elektrolytischen Hypothalamusläsionen. Acta neuroveg. 19, 250-257.

- VARga, F. Fohl, E. \& Herm, T., 1962. A koraszülött O2-fogyasztása hyper-és hypothermiában. (Oxygen consumption of the premature infant in byper- and hypothermia.) Orv. Hétil. 103, 677-681.

O'Connor, J. M., 1949. The control of the body temperature by fatty acid monolayers. Discuss. Faraday Soc. 6, 160-165.

Smith, R. E., 1962. Thermoregulation by brown adipose tissue in cold. Fedn Proc. Fedn Am Socs exp. Biol. 21, 221.

- 1964. Thermoregulatory and adaptive behavior of brown adipose tissue. Science, N.Y. 146, 1686-1689.

- \& Носк, R. J., 1963. Brown fat: thermogenic effector of arousal in hibernators. Science N.Y. 140,199-200.

- \& RonerTs, J. C., 1964. Thermogenesis of brown adipose tissue in cold-acclimated rats. Am. J. Pbysiol. 206, 143-148.

Szegvari, Gy,, VÁrnai, I. \& Donhofper, Sz., 1963. The effect of environmental temperature, hypoxia and hypercapnia on total heat production and on the electrical activity of muscle in the rat. Shivering and non-shivering thermogenesis and the site of non-shivering heat production. Acta physiol. bung. 23, 49-62.

Terromne, E. F. \& Roche, J., 1925. La respiration des tissues. 1. Production calorique des homéothermes et intensité de la respiration in vitro des tissus homologues. Archs int. Physiol. 24, 356-399.

WeYMOUTH, F. W. \& FIELD, J. II., 1942. Relationship between body size and metabolism. Proc. Soc. exp. Biol. Med. 49, 367-370.

\section{Diskussion im Anschluß an den Vortrag DoNHOFFER}

BRÜck: Läßt sich aus Ihren Befunden schon erkennen, ob der Anteil der Oz-Aufnahme, der nach Hypothalamusläsionen die nach der RGT-Regel zu erwartende $\mathrm{O}_{2}$-Aufnahme übersteigt, auf Muskelaktivität oder auf Stoffwechselsteigerungen in anderen Organen - wie etwa im braunen Fett - zurückzuführen sind?

DONHOFfer: Ihre Frage ist nicht leicht zu beantworten. Eine gewisse Regulation muß man voraussetzen. Setzt man die Tiere der Kälte aus, so erhält man die gezeigten Resultate. Setzt man die Tiere der Wärme aus, so findet man dieses Herausspringen des braunen Fettes überhaupt nicht.

SCHARF: Die Interpretation von Eingriffen am Dienkephalon ist nicht einfach. Zwei Haupt- 
effekte sind zu unterscheiden, die bei Ihren Untersuchungen in Frage kommen: (1) Störung des Zwischenhirn-Hypophysen-Schilddrüsen-Systems. Sie läßt sich dadurch kontrollieren, daß man nur den Hypophysenstiel durchschneidet (M. A. Greer, J. clin. Endocrinol. Metab. 12, 1259, 1952; Endocrinology 57, 755, 1955). Diese Operation müßte ähnliche Folgen haben wie die $Z$ wischenhiraläsion. (2) Störung des Adrenocortex-Pankreasinsel-Apparates, die auf einen gezielten Eingriff in das Zuckerverarbeitungssystem hinauskommt. Der Nachweis ließe sich führen, wenn man die Nebennieren histologisch untersucht und (nur notfalls: oder) die Corticoide auftrennt. Außerdem sollte man den Inselquotienten $Q_{I}=\frac{B-Z \text {-Zllenzahl }}{\text { A-Zellenzahl exakt er- }}$
mitteln.

DONHOFFER: Natürlich gibt es diese Mechanismen. Die Veränderungen treten aber je nach den Läsionen schlagartig ein und kommen nach einer gewissen Zeit zur vollkommenen Restitution. Es handelt sich bei den Versuchen um die verschiedenartigsten Folgen, die wir anatomisch auch nicht scharf lokalisieren konnten.

STRUBELT: Haben Sie den Sauerstoffverbrauch integral über einen größeren Zeitraum gemessen oder blieb er von vornherein konstant?

DONHOFFER: Der $\mathrm{O}_{2}$-Verbrauch wurde über drei 15 -min-Perioden gemessen, nachdem sich das Tier 25 bis $30 \mathrm{~min}$ bei einer bestimmten Temperatur befunden hatte. Viele Läsionen bedingen eine gleichzeitige Störung der chemischen Regulation und der Regulation der Körpertemperatur; ich wollte solche Fälle zeigen, in denen diese Reaktionen dissoziieren.

Strubelt: Wenn Sie den Sauerstoffverbrauch mit einer Apparatur messen, die ihn kontinuierlich für jede Minute registriert, erhalten sie einen initialen Abfall und nach 10 min eine gegenregulatorische Steigerung. Messen Sie integral über 15 min, entsteht der Eindruck, als ob der $\mathrm{O}_{2}$-Verbrauch konstant geblieben sei. In Wirklichkeit handelt es sich um zwei voneinander getrennt ablaufende Vorgänge.

DONHOFfer: Auch bei kurzfristigen Messungen haben wir keinen vorübergehenden Abfall des Sauerstoff verbrauches gesehen.

ZEISBERGER: ( 1 ) Were the animals used in your experiment adapted to a certain temperature? According to our experiments a correlation exists between the acclimation temperature and the amount of nonshivering heat production. The rats acclimated to $0^{\circ}$ and $-4^{\circ} \mathrm{C}$ respectively had the greatest nonshivering heat production. Animals adapted to $+30^{\circ}$ did not use the nonshivering heat production of noradrenaline type and used the shivering heat production instantaneously after cold exposition. (2) Did you measure the colonic temperature? At what time was the temperature change presented in your pictures measured?

DONHOFfer: Our animals were adapted to room temperature. In part of the experiments colonic temperature was measured continuously, in other experiments we measured at the end of the $\mathrm{O}_{2}$-consumption measurements, that is, about $1 \frac{1 / 2}{2}$ hour after the animals became adapted. WIESER: Ihre Versuche lassen sich so deuten, daß es eine Umschaltung von zentraler zu peripherer Thermogenese gibt, ohne daß es hierbei zu einer Verminderung des Sauerstoffverbrauchs kommt. Ergänzend möchte ich auf den Befund von $\mathrm{H}$. Rohracher. (Wien) hinweisen, der die Mikroschwingungen von Muskeln untersudhte. Er fand, daß deren Frequenz bei Transferierung der Tiere von der Kälte in die Wärme unerwarteterweise zunimmt. Eine Erklärung wäre möglich, wenn man eine zentral gesteuerte Verlagerung von zentraler zu peripherer Thermogenese annimmt und wenn bei letzterer mehr Wärme abgestrahlt wird als bei ersterer.

DONHOFFER: Sicher spielt bei der Thermogenese die elektrische Aktivität der Muskeln eine Rolle. SCHARF: Experimentell zu unterscheiden sind Auskünfte über das schnelle (sec, min), das mittelschnelle (Std., Tage) und das träge (Tage, Wochen) arbeitende System der Stoffwechselregulationen. Rasch reagierende Regulationen können nur mit automatischen Dauerregistrierungen zu sinnvollen Ergebnissen führen, am geeignetsten sind Meß-Registrierverfahren nach dem Prinzip der Leitfähigkeitsmessung. Für mittelschnell und träge arbeitende Regulationen ist die integrative Messung bequemer und billiger.

Donhoffer: Wir haben mit einer neuen Methode gearbeitet, die sehr schnelle, zugleich aber auch langfristige Messungen gestattet. 